\title{
Parasitological and immunological diagnoses from feces of captive-bred snakes at Vital Brazil Institute
}

\author{
Diagnóstico parasitológico e imunológico em fezes de serpentes cativas do Instituto Vital Brazil \\ Janaína Lima de Souza ${ }^{1}$; Alynne da Silva Barbosa ${ }^{1 *}$; Adriana Prado Vazon ${ }^{1}$; Claudia Maria Antunes Uchôa ${ }^{1}$; \\ Beatriz Coronato Nunes ${ }^{1}$; Myrian Bandeira Vianna Cortez²; Valmir Laurentino da Silva3; \\ Leonora Brazil Más ; Aníbal Rafael Melgarejo ${ }^{4}$; Otilio Machado Pereira Bastos ${ }^{1}$
}

\begin{abstract}
${ }^{1}$ Laboratório Parasitologia, Departamento de Microbiologia e Parasitologia, Instituto Biomédico, Universidade Federal Fluminense - UFF, Niterói, RJ, Brasil

${ }^{2}$ Laboratório de Microbiologia Ambiental, Departamento de Microbiologia e Parasitologia, Instituto Biomédico, Universidade Federal Fluminense - UFF, Niterói, RJ, Brasil

${ }^{3}$ Laboratório de Imunodiagnóstico, Departamento de Ciências Biológicas - DCB, Escola Nacional de Saúde Pública Sérgio Arouca - ENSP, Fundaçăo Oswaldo Cruz - FIOCRUZ, Rio de Janeiro, RJ, Brasil

${ }^{4}$ Divisão de Zoologia Médica, Instituto Vital Brazil, Niterói, RJ, Brasil
\end{abstract}

Received July 4, 2013

Accepted March 5, 2014

\begin{abstract}
Fecal samples from 56 snakes at the Vital Brazil Institute, in the city of Niterói, Rio de Janeiro, were tested using the sedimentation and flotation techniques to investigate the evolutionary forms of parasites such as helminths and protozoa, and using enzyme immunoassay techniques to detect antigens of Cryptosporidium sp. and Giardia sp. Among the animals tested, $80.3 \%$ were positive for parasites. Out of these, there were 16 Bothrops jararaca, 16 B. jararacussu and 13 Crotalus durissus. The prevalence of parasitic nematodes was $41.1 \%$, and nematodes were found in all three snake species. Among these, the most frequent finding was eggs of Kalicephalus sp., which were diagnosed in $25 \%$ of the snakes. The positivity for protozoa detected using parasite concentration techniques was $75 \%$, including oocysts of Caryospora sp. in 75\%, cysts with morphology similar to Giardia sp. 3.6\%, amoeboid cysts in $41.1 \%$ and unsporulated coccidia oocysts in $8.9 \%$. Immunoassays for Cryptosporidium sp. antigens produced positive findings in 60.7\%. Pseudoparasites were detected in $64.3 \%$. These results show that there is a need to improve the sanitary handling of captive-bred snakes, and also for the animal house that supplies rodents to feed them. The results also highlight that diagnostic tests should be performed periodically on stool specimens from captive-bred snakes.
\end{abstract}

Keywords: Antigens, ELISA, nematode parasites, snake, protozoa.

\section{Resumo}

Foram analisadas amostras fecais de 56 serpentes do Instituto Vital Brazil, Niterói, Rio de Janeiro, por técnicas de sedimentação e flutuação, para pesquisa de formas evolutivas de parasitos, como helmintos e protozoários, e utilizando técnica imunoenzimática para detecção de antígenos de Cryptosporidium sp. e Giardia sp. Dos animais estudados, $80,3 \%$ foram positivos para parasitos, dos quais 16 pertenciam à espécie Bothrops jararaca, 16 à B. jararacussu e 13 à Crotalus durissus. A prevalência de nematódeos parasitos foi de $41,1 \%$, sendo evidenciados nas três espécies de serpentes. Dentre estes, o mais frequente foi o encontro de ovos de Kalicephalus sp., diagnosticado em $25 \%$ das serpentes. A positividade para protozoários detectados pelas técnicas de concentraçáo foi de 75\%, nas quais oocistos de Caryospora sp. foram detectados em 75\%, cistos com morfologia similar a Giardia sp. em 3,6\%, cistos de amebídeos em 41,1\% e oocistos não esporulados de coccídios em 8,9\%. Obteve-se positividade para antígenos de Cryptosporidium sp. por imunoensaio em $60,7 \%$. Pseudoparasitos foram detectados em $64,3 \%$. Estes resultados apontam para a necessidade de aprimoramento do manejo sanitário das serpentes cativas, bem como no biotério que fornece roedores para sua alimentação, destacando a realização periódica de diagnóstico nas amostras fecais de serpentes cativas.

Palavras-chave: Antígenos, ELISA, parasitos nematódeos, serpente, protozoários.

\footnotetext{
*Corresponding author: Alynne da Silva Barbosa

Laboratório Parasitologia, Departamento de Microbiologia e Parasitologia,

Instituto Biomédico, Universidade Federal Fluminense - UFF, Rua Professor

Hernani Melo, 101, São Domingos, CEP 24210-130, Niterói, RJ, Brasil

e-mail: alynnedsb@gmail.com; alynnedsb@vm.uff.br
} 


\section{Introduction}

Snakes are susceptible to a wide array of parasites, which presents a major challenge to breeders (SILVA, 2000). These animals tend to present oligosymptomatic parasitism in their natural habitat, and symptomatic illnesses due to parasitism are only rarely found (SILVA et al., 2001).

In Brazil, the group of venomous snakes of medical interest includes the genera Bothrops, Crotalus and Lachesis in the family Viperidae, and the genus Micrurus in the family Elapidae (BRASIL, 2012). This country is home to the largest diversity of Viperidae belonging to the genus Bothrops, more commonly known as "jararaca" (MARTINS et al., 2001). Maintenance of snakes under captive conditions, especially venomous snakes, plays an important role in production of biopharmaceuticals and in research on toxinology (COSTA et al., 2005).

Nematodes such as Kalicephalus sp., a parasite infecting the esophagus, stomach and duodenum, are the most prevalent parasites in the digestive system of snakes. The severe infections caused by these helminths often lead to anorexia, with consequent reduction of body weight, and diarrheic, bloody and/or mucous stools (ARAÚJO et al., 1999). Some authors have reported that Kalicephalus sp., Ophidascaris sp. and Rhabdias sp. were detected through necropsy procedures (SILVA et al., 2001; DIAS et al., 2004). A few studies have detected protozoa, such as Caryospora sp., Sarcocystis sp. and Cryptosporidium sp. (O'DONOGHUE, 1995; KARASAWA et al., 2002; GREGO et al., 2004).

Rubião (1999) tested 75 fecal samples from snakes at the Vital Brazil Institute, in Niterói, state of Rio de Janeiro, and found 34 positive results for nematodes (45\%). Among these, Rhabdias sp. was the most common, followed by Kalicephalus sp. and Ophidascaris sp. Also through analyzing fecal samples, Araújo et al. (1999) found eggs of Ophidascaris, Kalicephalus and Oxyuris. Furthermore, reports in the literature have also indicated that pseudoparasites may be present, likely to have come from the animals ingested as food. The pseudoparasites most often reported in snakes have been Syphacia sp., Hymenolepis sp. and Aspiculurus sp. (RUBIÃO, 1999; RADHAKRISHNAN et al., 2009).

Research on the infectious, non-infectious and parasitic diseases that affect captive-bred snakes is a matter of some importance, since this serves as input for improving snake health conditions and optimizing venom production (IB, 2011). The present study aimed to evaluate the presence of evolutionary forms of parasites such as helminths and protozoa, and antigens of Giardia sp. and Cryptosporidium sp., in fecal samples from captive-bred snakes at the Vital Brazil Institute, in the city of Niterói, Rio de Janeiro, Brazil.

\section{Materials and Methods}

\section{Ethical considerations}

The tests were performed on fecal samples from captive-bred snakes that were reared separately, for maintenance purposes, in corrugated cardboard-lined plastic boxes, belonging to the Vital Brazil Institute. This study was approved by the Ethics Committee on Animal Use of the Fluminense Federal University (Universidade Federal Fluminense, UFF), under protocol no. 82/2011.

\section{Handling snakes at the Institute}

At the Vital Brazil Institute, snakes are kept in captivity in three rooms for the duration of their lives: one for Bothrops jararaca and Crotalus durissus, the second for the Bothrops genus and the third one for breeding assorted ophidian genera. The animals used for feeding the snakes are reared and supplied by the central animal house of the Vital Brazil Institute. The snakes are routinely subjected to antiparasitic treatment, in which an ivermectin solution (IVOMEC ${ }^{\circledR}$ ) is administered. The diluent for this is glycol propylene, at a dosage of $0.01 \mathrm{~mL}$ for each $50 \mathrm{~g}$ of weight, applied subcutaneously applied during the quarantine period, after arrival at the Institute.

\section{Fecal samples}

The study involved 56 snakes that were kept in captivity at the Vital Brazil Institute, of which 19 were Bothrops jararaca, 20 were Bothrops jararacussu and 17 were Crotalus durissus. The fecal samples were collected by means of a disposable plastic spatula from the maintenance box cardboard lining on different days, amounting to two samples per animal.

After sample collection, the material was placed in a plastic container without any preservative agent and was cold-stored $\left(4{ }^{\circ} \mathrm{C}\right.$ to $\left.8{ }^{\circ} \mathrm{C}\right)$ in an insulated container. It was then sent to the Parasitology Laboratory of the Fluminense Federal University's Biomedical Institute. Each fecal sample was processed separately, and the results were grouped per two samples from each single animal.

\section{Laboratory tests on fecal samples}

All the samples were initially processed and homogenized in $10 \mathrm{~mL}$ of phosphate-buffered saline solution [PBS; $0.1 \mathrm{M}$; $\mathrm{pH}=7.2]$, gauze-filtered and transferred to a conical-bottom glass for 24-hour sedimentation. The supernatant was disposed of and the sediment was adjusted for a final volume of $7 \mathrm{~mL}$, which was aliquoted into five portions, namely: $0.5 \mathrm{~mL}$ in Eppendorf microtubes for investigating Cryptosporidium sp. and Giardia sp. antigens using a commercial ELISA kit (enzyme immunoassay); $1.0 \mathrm{~mL}$ in Eppendorf microtubes for ELISA storage; $1.0 \mathrm{~mL}$ for the Ritchie (1948) technique, as modified by Young et al. (1979); $1.0 \mathrm{~mL}$ for Sheather (1923), as modified by Huber et al. (2003); $1.0 \mathrm{~mL}$ for Willis (1921); $1.5 \mathrm{~mL}$ for storage, adding $3 \mathrm{~mL}$ of Railliet \& Henry's solution. The sedimentation and flotation techniques used in this study show sensitivity for detection of evolutionary forms of protozoa and helminths present in stool samples.

The slides to which parasitological techniques were applied were read and photomicrographed using an Olympus ${ }^{\circledR}$ BX 41 optical microscope, initially at $100 \%$ magnification, and then at $400 \%$ magnification for confirmation. This microscope was coupled to a Samsung ${ }^{\circledR}$ SDC415 digital camera with Honestech ${ }^{\circledR}$ PVR capture software. To measure the evolutionary forms, an Olympus ${ }^{\circledR} \mathrm{CH} 30$ 
optical microscope at $400 \%$ magnification was used, along with an Olympus ${ }^{\circledR}$ SWH ocular micrometer.

The samples in Eppendorf microtubes were processed using the ELISA method, with the aim of increasing the detection of cysts of Giardia sp. and Cryptosporidium sp. Commercial kits for detecting Giardia and Cryptosporidium antigens in stools through ELISA microwell assays (IVD Research, Inc. ${ }^{\circledR}$ ) were also used. Enzyme immunoassays were carried out in accordance with the manufacturer's guidelines, considering the diluted or diarrheic samples as the parameter. The plates were read using an ELISA reader (ThermoPlate ${ }^{\circledR}$ multiplate reader), which was gauged according to wavelength, in keeping with the technical standards recommended by the manufacturer.

\section{Results}

Out of the 56 animals tested, 45 (80.3\%) were positive for evolutionary forms of parasites of the pulmonary or gastrointestinal tract of snakes. Among these, there were $16 \mathrm{~B}$. jararaca, $16 \mathrm{~B}$. jararacussu and 13 C. durissus. Caryospora sp. was the most frequent parasite, found in $42 / 56$ (75\%) of the animals.

The prevalence of evolutionary forms of parasitic nematodes was $41.1 \%(23 / 56)$, and these nematodes were found in three of the snake species tested. Kalicephalus sp. was the predominant helminth (Figure 1A), detected in 14/56 (25\%). Eggs of species in the family Ascaridae, superfamily Rhabditoidea (Figure 1B), and larvae of nematodes were found. It was found that $42 / 56$ (75\%) of the snakes were positive for Caryospora sp. oocysts (Figure 1D): 15 of the species B. jararaca, 13 B. jararacussu and 14 C. durissus. Sarcocystis sp. (Figure 1C) was detected in 6/56 (10.7\%) of the snakes: three of the species B. jararaca, one B. jararacussu and two $C$. durissus species. Cyst morphology similar to Giardia sp. was also detected in $2 / 56(3.6 \%)$, in the species $B$. jararaca, as well as amoeboid cysts in 23/56 (41.1\%) and unsporulated coccidian oocysts in 5/56 (8.9\%) of the animals (Table 1 ).

Evolutionary forms of pseudoparasites were detected in 36/56 (64.3\%) of the snakes. The species Rodentolepis sp. was found in $12 / 56(21.4 \%)$ of the animals, Syphacia sp. in 26/56 (46.4\%) and Aspiculuris sp. in 8/56 (14.3\%). Moreover, there was an association
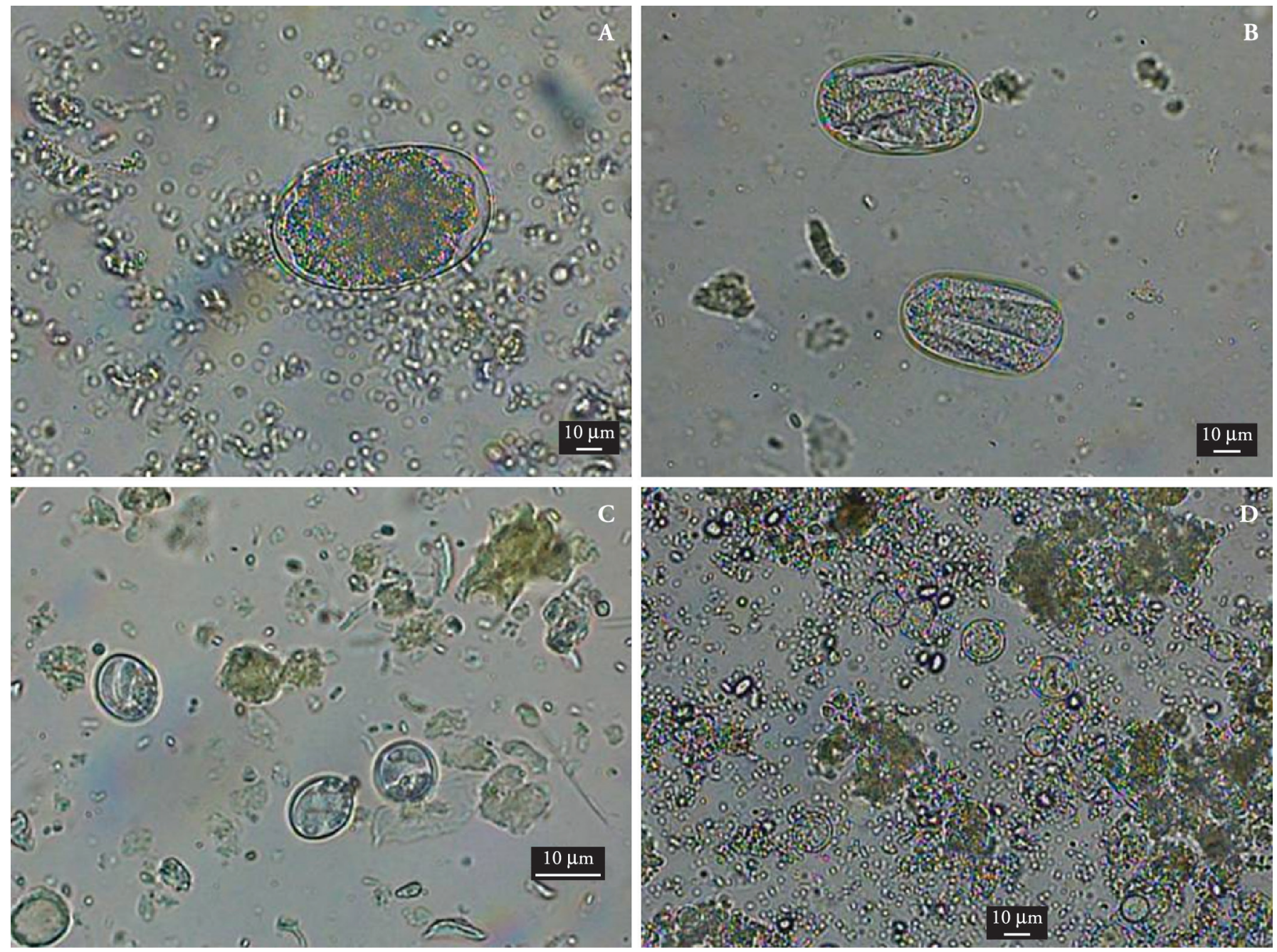

Figure 1. Ilustration of evolutionary forms of the snakes parasites found by microscopie stool diagnosis techniques. A - Kalicephalus sp.

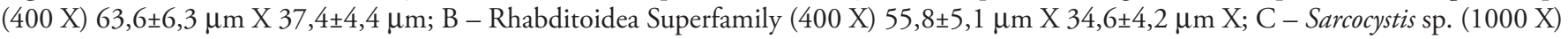
$8,7 \pm 3,3 \mu \mathrm{m}$; and D - Caryospora sp. (400 X) $6 \pm 1 \mu \mathrm{m}$. 
Table 1. Evolutionary forms of protozoa, helminthes and anthrops detected in fecal samples of 56 captive-bred serpents of the Bothrops jararaca, Bothrops jararacussu and Crotalus durissus species.

\begin{tabular}{|c|c|c|c|c|}
\hline & Bothrops jararaca & Bothrops jararacussu & Crotalus durissus & \\
\hline Evolutionary forms & $\mathrm{N}=19$ & $\mathrm{~N}=\mathbf{2 0}$ & $\mathrm{N}=17$ & Total \\
\hline Eggs of Ascaridae Family* & 2 & 1 & 5 & $8(14.3 \%)$ \\
\hline Kalicephalus sp.* & 5 & 6 & 3 & $14(25 \%)$ \\
\hline Rhabditoidea Superfamily* & 0 & 3 & 2 & $5(8.9 \%)$ \\
\hline Caryospora sp.* & 15 & 13 & 14 & $42(75.0 \%)$ \\
\hline Sarcocystis sp.* & 3 & 1 & 2 & $6(10.7 \%)$ \\
\hline Giardia sp. cysts with similar morphology & 2 & 0 & 0 & $2(3.6 \%)$ \\
\hline Amoeboid cyst & 7 & 9 & 7 & $23(41.1 \%)$ \\
\hline Unsporulated coccidia oocysts & 1 & 0 & 4 & $5(8.9 \%)$ \\
\hline Larvae & 0 & 6 & 4 & $10(17.9 \%)$ \\
\hline Acarus egg & 19 & 19 & 17 & $55(98.2 \%)$ \\
\hline Aspiculuris sp. ${ }^{* *}$ & 3 & 2 & 3 & $8(14.3 \%)$ \\
\hline Syphacia sp.** & 8 & 10 & 8 & $26(46.4 \%)$ \\
\hline Rodentolepis sp.** & 5 & 5 & 3 & $12(21.4 \%)$ \\
\hline
\end{tabular}

*Parasites specific to serpentes; ${ }^{* *}$ Pseudoparasites - Parasites of other animals that are used for feeding serpents with evolutionary forms detected in feces.

with evolutionary forms of pseudoparasites of different genera. Acarid eggs were found in samples from 55/56 (98.2\%) of the animals (Table 1).

All of the fecal samples from the snakes tested were negative for antigens of Giardia sp., using ELISA. Using the same technique, antigens of Cryptosporidium sp. were found in 18 specimens of $B$. jararaca, 11 B. jararacussu and five $C$. durissus, thus giving rise to prevalence of $60.7 \%(34 / 56)$ (Table 2$)$.

\section{Discussion}

The parasite prevalence detected among the Vital Brazil Institute's captive-bred snakes was $80.3 \%$. This result was lower than that found by Radhakrishnan et al. (2009), who observed that 22 out of 25 snakes $(88 \%)$ at three different herpetariums in the state of Kerala, India, presented parasitic forms in fecal samples. In turn, Rubiāo (1999) found that nematodes were present in $45 \%$ of 75 fecal samples from snakes at the Vital Brazil Institute, Niterói, Rio de Janeiro. The prevalence of nematodes revealed by the present study was $41.1 \%(23 / 56)$, which was lower than that determined by Silva et al. (2001) among 24 rattlesnakes in São Paulo, who found that $70.8 \%$ of the samples were positive for nematodes.

Kalicephalus sp. was the most prevalent nematode, detected in $25 \%(14 / 56)$ of the snakes. The rate of positive findings for this helminth is consistent with the results of Grego et al. (2004), who tested 131 jararacas at the Butantan Institute of São Paulo, by means of necropsy. In contrast, Rubião (1999), who tested snakes at the Vital Brazil Institute, found that Rhabdias sp. nematodes predominated. The occurrences of Kalicephalus sp. in three different species of snakes may be explained by the poor specificity of this parasite, in view of its direct cycle (SILVA et al., 2001), which promotes its circulation in the propagation environment. Schad (1956) suggests that the snake's behavior of searching the environment with its tongue may set the stage for transmission of parasitoses.

The second most prevalent helminth was roundworms of the family Ascaridae such as Ophidascaris sp. or Travassosascaris
Table 2. Result of Enzyme immunoassay for survey of antigens of Cryptosporidium sp. in fecal samples of 56 serpents of Bothrops jararaca, Bothrops jararacussu and Crotalus durissus species.

\begin{tabular}{llcc}
\hline & \multicolumn{2}{c}{ ELISA } \\
\hline \multicolumn{1}{c}{ Species } & N & Positive & Negative \\
\hline Bothrops jararaca & 19 & 18 & 1 \\
Bothrops jararacussu & 20 & 11 & 9 \\
Crotalus durissus & 17 & 5 & 12 \\
\hline
\end{tabular}

araujoi. These parasites have an indirect cycle, with terrestrial invertebrates and small mammals as intermediate hosts, and transmission under conditions of captivity is rare, but cannot be ruled out (DIAS et al., 2004). Findings of these threadworms imply that these snakes arrived from their natural biome already infected, and that the initial handling at the Institute failed to eradicate this parasite.

Only a few parasite surveys on snakes based on fecal samples have detected protozoa, such as in Barbosa et al. (2006). High prevalence of protozoa was found in the present study, with predominance of the parasite Caryospora sp.. This had already been described for several snakes elsewhere in the world (SEVILLE et al., 2005; MODRÝ; KOUDELA, 1998) and in Brazil (LAINSON et al., 1991). In addition to Caryospora sp., cysts with morphology similar to Giardia sp., amoebae, unsporulated coccidia oocysts and sporocysts of Sarcocystis sp. were also found. The methodology used may have led to the lack of data about protozoa in herpetology, since most studies have used necropsies to recover parasites. Alternatively, the lack of data may have been associated with the type of laboratory technique chosen for parasitological investigations of feces, relating to the difficulty of viewing evolutionary forms of protozoa in microscopic preparations.

Two fecal samples per snake were used in the present study to improve the efficiency of parasitological diagnoses. Cartwright (1999) claimed that testing two feces samples on different days increased the sensitivity of detection of evolutionary forms of parasites to $92 \%$. Accordingly, this author correlated parasitological 
techniques based on different assumptions with the enzyme immunoassay for diagnosing Giardia sp. and Cryptosporidium sp. antigens.

Evolutionary forms of pseudoparasites were found in 64.3\% of the fecal samples of the snakes studied here, and were present in the three snake species at similar prevalence rates. Syphacia sp. was the predominant genus, followed by Rodentolepis sp. The presence of these pseudoparasites was also reported by Radhakrishnan et al. (2009), and Rodentolepis sp. was the prevalent species. Rubião (1999) also reported pseudoparasites in his study, with predominance of Syphacia sp., which is consistent with the data found in the present study. Based on the detection rates for pseudoparasites in other studies (RUBIÃO, 1999; RADHAKRISHNAN et al., 2009), it is possible to conclude that the animal houses that provide animals to feed snakes kept for research purposes do not have good control over the intestinal parasites that are common among the species of rodents bred in these establishments.

Furthermore, discordance has been found between the results from microscopic and immunological concentration techniques for detecting antigens of Cryptosporidium sp. and Giardia sp. In diagnosing Giardia sp., cysts resembling those of this parasite were found in two jararacas through microscopy without correspondence to ELISA results. The difference between the results may have occurred due to the small quantity of evolutionary forms of the parasite and, consequently, the small quantity of antigens in the sample, on random dispersion. The absence or small quantity of antigens may have been triggered by addition of samples on different days. Thus, the aliquots used for ELISA presented absence or low quantities of antigen, i.e. below the detection capacity of the test.

Cryptosporidium sp. was detected in 34 animals (60.7\%), although the ELISA kit used was only able to detect the genus, and differentiation between the pathogenic and pseudoparasitic species affecting snakes was not possible. Ruggiero et al. (2011), researching several snake species at the Butantan Institute in São Paulo, found after applying specific staining and molecular techniques that the prevalence of Cryptosporidium sp. was $44 \%$ (4/10), and that the highest number of positive results was among rattlesnakes $(57.14 \% ; 4 / 7)$. In the present study, B. jararaca was the species presenting highest prevalence of Cryptosporidium sp., with positive findings in $94.7 \%(18 / 19)$, while $C$. durissus was the least prevalent $(29.4 \%$; 5/17).

Collection of samples directly from the bottom lining of the snakes' maintenance boxes aided in finding acarid eggs in almost all of the fecal samples from these snakes. No ectoparasitism evaluation was performed. Therefore, it was not possible to ascertain if the acarid eggs were parasitic or free-living. Nonetheless, they were indicators of the sensitivity of the microscopic techniques used in the diagnostic stool analysis.

The study by Rubião (1999) and the present study were both developed at the Vital Brazil Institute, at different times. It could be seen that the same parasite species were circulating, taking into account both parasites and pseudoparasites that are specific to snakes. This leads to the assumption that the antiparasitic treatment has not been successful. This lack of successful therapy may be explained by improper therapeutic schemes, underdosage, parasite resistance or use of drugs that were not effective for certain parasites. Moreover, there is also the possibility of infection transferred through routine handling of the snakes, thereby facilitating transmissibility of evolutionary forms of the parasites.

\section{Conclusions}

The results from this study demonstrate that parasites of snakes at the Vital Brazil Institute occur at high levels and that there is a need to assess the maintenance and management conditions of these animals. This should be extended to the entire team, as well as to the animal house that provides animals to feed the snakes.

\section{Acknowledgments}

We would like to thank the Serpentarium division of the Vital Brazil Institute for allowing this research, CNPq (Brazilian Council of Scientific and Technological Development), and the Dean's Office for Graduate, Research Studies and Innovation of Federal Fluminense University.

\section{References}

Araújo T, Moro L, Lúcia M, Golloubeff B, Vasconcelos AC. Ocurrence of some endo and ectoparasites in the serpentarium of UNIFENAS. Braz J Vet Res Anim Sci 1999; 36(1): 19-22.

Barbosa AR, Silva H, Albuquerque HN, Ribeiro IAM. Contribuiçáo ao estudo parasitológico de jibóias, Boa constrictor constrictor Linnaeus, 1758, em cativeiro. Rev Biol Ciên Ter 2006; 6(2): 1-19.

Brasil. Ministério da Saúde. Secretaria de Vigilância em Saúde - SVS. Guia de vigilância epidemiológica. Brasília: MS; 2012. Caderno 14 [cited 2012 Mai 2]. Available from: http://portal.saude.gov.br/portal/arquivos/pdf/ gve_7ed_web_atual_aap.pdf.

Cartwright CP. Utility of multiple-stool-specimen ova and parasite examinations in a high-prevalence setting. J Clin Microbiol 1999; 37(8): 2408-2411. PMid:10405376 PMCid:PMC85240.

Costa ACORC, Almeida-Santos SM, Germano VJ, Oliveira L, Scartozzoni RR, Salomão MG. Manutenção de serpentes em cativeiro no Instituto Butantan: I - A longevidade dos gêneros Bothrops, Crotalus e Lachesis. Publ Avulsas Inst Pau Bras 2005; 8-9: 63-68.

Dias RJP, Almeida SJB, Prieto DB, Lima SS. Aspectos ecológicos dos nematóides parasitos de Crotalus durissus terrificus Laurenti, 1768 (Ophidia, Viperidae), em Juiz de Fora, Minas Gerais, Brasil. Rev Bras Zoocienc 2004; 6(2): 219-230.

Grego KF, Gardiner CH, Catáo-Dias JL. Comparative pathology of parasitic infections in free-ranging and captive pit vipers (Bothrops jararaca). Vet Rec 2004; 154(18): 559-562. PMid:15144001. http:// dx.doi.org/10.1136/vr.154.18.559

Huber F, Bomfim TC, Gomes RS. Comparação da eficiência da técnica de sedimentação pelo formaldeído-éter e da técnica de centrífugoflutuação modificada na deteç̧áo de cistos de Giardia sp. e oocistos de Cryptosporidium sp. em amostras fecais de bezerros. Rev Bras Parasitol Vet 2003; 12(2): 135-137.

Instituto Butantan - IB. Laboratório de herpetologia. São Paulo: IB; 2011 [cited 2011 Mar 7]. Available from: http://www.butantan.gov.br/home/ laboratorio_de_herpetologia.php. 
Karasawa ASM, Silva RJ, Mascarini LM, Barrella TH, Lopes CAM. Occurrence of Cryptosporidium (Apicomplexa, Cryptosporidiidae) in Crotalus durissus terrificus (Serpentes, Viperidae) in Brazil. Mem Inst Oswaldo Cruz 2002; 97(6): 779-781. http://dx.doi.org/10.1590/S007402762002000600004

Lainson R, Nascimento FP, Shaw JJ. Some new species of Caryospora (Apicomplexa: Eimeriidae) from brazilian snakes, and a re-description of C. jararacae Carini, 1939. Mem Inst Oswaldo Cruz 1991; 86(3): 349-364. http://dx.doi.org/10.1590/S0074-02761991000300009

Martins M, Araújo MS, Sawaya RJ, Nunes R. Diversity and evolution of macrohabitat use, body size and morphology in a monophyletic group of neotropical pitvipers (Bothrops). JZool 2001; 254(4): 529-538. http:// dx.doi.org/10.1017/S0952836901001030

Modrý D, Koudela B. Coccidia of genus Caryospora (Apicomplexa: Eimeriidae) from the long nosed vine snake, Ahaetulla nasuta (Serpentes: Colubridae: Boiginae) from southern India, with a description of $C$. veselyi sp. Folia Parasitol 1998; 45: 167-169.

O’Donoghue PJ. Cryptosporidium and Cryptosporidiosis in man and animals. Int J Parasitol 1995; 25(2): 139-195. http://dx.doi. org/10.1016/0020-7519(94)E0059-V

Radhakrishnan S, Kurup SP, Banerjee PS. Endoparasitism in captive wildcaught snakes indigenous to Kerala, India. Zoo Biol 2009; 28(3): 253258. PMid:19504599. http://dx.doi.org/10.1002/zoo.20231

Ritchie LS. An ether sedimentation technique for routine stool examinations. Bull US Army Med Dep 1948; 8(4): 326.

Rubião ECN. Nematóides parasitas de jararaca (Bothrops jararaca Wied, 1824) mantidas no serpentário do Instituto Vital Brazil: aspectos patológicos [Dissertaçâo]. Niterói: Faculdade de Medicina Veterinária da Universidade Federal Fluminense; 1999.

Ruggiero PC, Zacariotti RL, Bondan EF, Lallo MA. Prevalência de Cryptosporidium serpentis em serpentes de cativeiro. Ciênc Rural 2011; 41(11): 1975-1978. http://dx.doi.org/10.1590/S010384782011001100020

Seville RS, Asmundsson IM, Campbell JA. Descriptions of six new species of Caryospora (Apicomplexa: Eimeriidae) from Guatemalan snakes (Serpentes: Colubridae and Viperidae). J Parasitol 2005; 91(6): 1452 1458. PMid:16539030. http://dx.doi.org/10.1645/GE-588R.1

Schad GA. Studies on the genus Kalicephalus (Nematoda: Diaphanocephalidae). I. On the life histories of the North American Species $K$. parvus, $K$. agkistrodontis, and $K$. rectiphilus. Can J Zool 1956; 34(5): 425-452. http://dx.doi.org/10.1139/z56-047

Sheather AT. The detection of intestinal protozoa and monge parasites by a flotation technique. J Comp Pathol 1923, 36: 266-275. http://dx.doi. org/10.1016/S0368-1742(23)80052-2

Silva R. As serpentes. Jaboticabal: FUNEP; 2000. p. 46.

Silva RJ, Barrella TH, Nogueira MF, O’Dwyer LH. Frequency of Helminths in Crotalus durissus terrificus (Serpentes, Viperidae) in captivity. Rev Bras Parasitol Vet 2001; 10(2): 91-93.

Willis II. A simple levitation method for the detection of hookworm ova. Med J Australia 1921; 8: 375-376.

Young KH, Bullock SL, Melvin DM, Spruill CL. Ethyl Acetate as a substitute for diethyl ether in the formalin-ether sedimentation tecnique. J Clin Microbiol 1979; 10(6): 852-853. PMid:574877 PMCid:PMC273283. 